Marquette University

e-Publications@Marquette

4-1-1978

Errors in the Measurement of Concentration and the Advertising-Concentration Controversy

Brian Brush

Marquette University, brian.brush@marquette.edu

Published version. Southern Economic Journal, Vol. 44, No. 4 (April 1978): 978-986. Stable URL. (C) 1978 Southern Economic Association. Used with permission. 


\section{Errors in the Measurement of Concentration and the Advertising-Concentration Controversy*}

\section{Introduction}

While numerous empirical studies of the advertising-concentration relationship have been published in the last fifteen years, two recent studies by Ornstein $[4 ; 5]$ represent something of a breakthrough in this ongoing controversy. ${ }^{1}$ For the first time the relationship has been tested using a large sample of four-digit Census manufacturing industries, and for the first time, the advertising data employed, taken from the U.S. input-output tables, appear to be matched well to the specific four-digit Census industries for which the concentration ratios are measured, eliminating the need for matching by judgment. Thus, many of the problems associated with previous studies, which employed Internal Revenue Service or trade publication advertising data, have been overcome.

The results of Ornstein's statistical tests led him to conclude that: (1) there is a positive and statistically significant linear relationship between advertising and concentration; (2) the quantitative impact of concentration on advertising is weak; (3) since a statistically significant but weak relationship shows up even in producer goods industries, the relationship is probably spurious, the result of "large-firm effects"; and (4) there is no evidence of a quadratic relationship between advertising and concentration. ${ }^{2}$

\footnotetext{
*This research was supported by a Summer Faculty Fellowship awarded by the College of Business Administration at Marquette University.

1. The 1977 Ornstein study [5] is a somewhat expanded version of his 1976 study [4], presenting results for 1947, 1963, and 1967, while the 1976 study presented results for 1963 only. Both studies drew upon the same data sources, involved exactly the same statistical tests, and reached the same general conclusions.

2. In a study utilizing a nearly complete sample of four-digit Census manufacturing industries for 1963, Strickland and Weiss [8] also used the input-output advertising data but arrived at substantially different conclusions on the advertising-concentration relationship. However, as Ornstein has pointed out, the larger sample employed by Strickland and Weiss (408 industries vs. 329 industries in Ornstein's 1963 sample) may have been obtained at the cost of introducing substantial measurement errors with respect to the advertising variable. While Ornstein's advertising-sales ratios exactly match a single four-digit Census industry for all 329 industries in his sample, the Strickland-Weiss advertising-sales ratios exactly match a single four-digit Census industry in only 230 of their 408 cases. In the other cases, a single advertising-sales ratio is used to represent more than one Census industry in the sample. See Strickland and Weiss [8, 1114-15], and Ornstein [5, 37].
} 
While these conclusions of Ornstein may engender somewhat greater confidence than those of previous studies, there remains at least one potentially serious statistical problem which Ornstein's studies have not come to grips with and which continues as a source of skepticism. It is generally accepted that many of the four-digit Census industry definitions correspond poorly to the economic concept of an industry or market. Some industry definitions are too broad, lumping together numerous non-competing products, whereas other industry definitions are too narrow, separating close substitute products into two or more Census industries. Furthermore, the official Census concentration ratios fail to reflect the fact that for some industries, markets are regional or local rather than national in scope, and also the fact that in some industries, imports account for a significant share of the market. ${ }^{3}$

As a result of these problems the official Census concentration ratios often seriously understate, and sometimes seriously overstate, the true extent of concentration within well-defined markets. Thus, even if the input-output advertising data accurately reflect the average advertising intensity for those products assigned to each four-digit Census industry, the errors in the measurement of concentration due to faulty industry or market definition may result in the attenuation of the observed statistical relationship between advertising and concentration. ${ }^{4}$ It is conceivable that, if these measurement errors could be corrected, the association between advertising and concentration might turn out to be much closer than Ornstein's results make it appear to be. It is the purpose of this paper to present evidence on the effects such errors in the measurement of concentration actually have on the observed statistical relationship between advertising and concentration.

\section{The Data and Statistical Tests}

It is unfortunate that correcting the official Census concentration ratios for all of their potential errors represents a formidable undertaking that is only rarely attempted. Fortunately, the attempt has been made recently by Shepherd [7], who has "adjusted" the official 1966 four-firm concentration ratios for all four-digit Census manufacturing industries in order to correct for the sources of error described in the previous section. Shepherd found a need for adjustment in 225 of the $\mathbf{4 1 7}$ manufacturing industries, and the adjustments are often substantial, raising the weighted average four-firm concentration ratio from 39 to 60 percent. While admittedly subjective, Shepherd's adjustments correct for the more glaring errors in Census concentration ratios, and

3. For a discussion of these problems and the errors they introduce into the Census concentration ratios, see Bain $[1,124-33]$, and Scherer [6, 52-57].

4. An excellent discussion of attenuation can be found in Yule and Kendall [9, 313-15]. 
in Shepherd's words, "Although other researchers might differ on details, they would probably reach the same general results" $[7,108]$.

Shepherd's adjusted concentration ratios apply to 1966. Since the closest year for which input-output advertising data are available is 1967, we propose to re-test the advertising-concentration relationship using the 1967 inputoutput advertising data and the official 1967 Census concentration data, substituting the Shepherd concentration figures for those industries for which Shepherd has found an adjustment necessary. ${ }^{5}$ We can then compare these results with those obtained from use of the official concentration ratios for all industries. To avoid any questions about the effects of different samples on the results, we shall make use of Ornstein's 1967 sample [5] of 324 four-digit Census manufacturing industries, each industry being classified according to whether its products are producer or consumer goods, and also according to whether its products are durable or non-durable.

We shall estimate the following two equations,

$$
\begin{aligned}
& A S R=a_{1}+b_{1} C R+e_{1} \\
& A S R=a_{2}+b_{2} C R+c_{2} C R^{2}+e_{2}
\end{aligned}
$$

where $A S R$ is the industry advertising-sales ratio, $C R$ is the industry fourfirm concentration ratio, and $e$ is the error term. In each of Ornstein's studies, he estimated four separate single-equation models. The first two equations tested for linear and quadratic relationships, respectively, between advertising intensity (the advertising-sales ratio) and concentration, represented by the four-firm concentration ratio, while the remaining two equations tested for linear and quadratic relationships between absolute advertising expenditures and concentration. ${ }^{6} \mathrm{He}$ argues correctly that the use of absolute advertising may be more appropriate than advertising intensity if there are economies of scale in advertising such that high advertising causes high concentration. However, his own survey of the empirical evidence finds little support for the economies of scale hypothesis. On the other hand, Ornstein does not seem to recognize that, if concentration is causally prior to advertising because increasing concentration results in greater oligopolistic interdependence which shifts competitive emphasis away from price into non-price forms (an argument Ornstein

5. The data used in this study can be found in Ornstein [5, Appendix B], and Shepherd [7, Appendix Table 8]. The fact that the Shepherd data pertain to 1966 instead of 1967 is of minimal significance, since in most cases the official concentration ratios changed very little between 1966 and 1967.

6. The first two of Ornstein's equations were identical to those to be estimated in this study. The remaining two were as follows:

and

$$
\log A=a_{3}+b_{3} C R+c_{3} \log S+e_{3},
$$

$$
\log A=a_{4}+b_{4} C R+c_{4} C R^{2}+d_{4} \log S+e_{4},
$$

where $A$ is absolute advertising expenditures, $C R$ is the four-firm concentration ratio, $S$ is industry sales, and $e$ is the error term. 
does not seem to dispute), the use of advertising intensity may be just as appropriate. If an increase in concentration increases competitive advertising in an absolute sense, it will also increase industry advertising intensity, provided only that industry demand is relatively inelastic with respect to total industry advertising expenditures, a condition that would normally be satisfied in equilibrium even in the absence of competitive advertising. If concentration is causally prior to advertising, a second consideration then tips the scales in favor of using advertising intensity as the dependent variable. The advertising-sales ratio can be interpreted as the proportion of sales revenue that is spent on advertising, which if used with appropriate caution may be one of a number of useful indicators of industry performance. ${ }^{7}$

In what follows, then, we shall present linear and quadratic regression results using the advertising intensity variable only, although it is noteworthy that Ornstein's general conclusions were the same regardless of which advertising variable was used. Both the economies of scale and oligopolistic competition arguments are compatible with a linear specification for the estimating equation, although each implies a different direction of causation. The quadratic specification favored by Greer [3], Cable [2], and others results from an extension of the oligopolistic competition argument. Proponents of the quadratic hypothesis have argued that as concentration increases, competitive advertising causes advertising intensity to rise, but that beyond some point, the heightened sense of mutual interdependence brought about by rising concentration leads to collusion on advertising, so that further increases in concentration result in a reduction in advertising intensity. As previously noted, Ornstein found no support for the quadratic hypothesis, but it is nonetheless appropriate to re-test both the linear and quadratic specifications using the adjusted concentration data.

\section{The Statistical Results}

The results using the linear specification are shown in Table I. Equations (1-a) and (1-b) in Table I show results for all consumer goods industries using the official concentration data and the Shepherd concentration data, respectively. ${ }^{8}$ Use of the adjusted data brings about a very slight increase in the coefficient of determination $R^{2}$ (corrected for degrees of freedom) from .086 to .094 , and also a slight increase in the size of the regression coefficient. For the non-

7. For a discussion of selling costs as an indicator of industry performance, see Bain [1, 412-18].

8. The slight difference in our results with the official concentration ratios and the results presented in Ornstein [5, 50], for consumer goods industries is apparently due to the fact that Ornstein used an incorrect concentration ratio (7) for the shoe industry (SIC 3141) in his regressions. The correct figure is 27. 
Table I. Regressions of $A S R$ on $C R, 1967$

\begin{tabular}{|c|c|c|c|c|c|c|}
\hline Equation & Data & Sample & $\mathbf{N}$ & Int ercept & CR & $\mathrm{R}^{2}$ \\
\hline$(1-a)$ & Census & Consumer & 87 & 1.1082 & $\begin{array}{l}0.0648 * * \\
(3.02)\end{array}$ & .086 \\
\hline (1-b) & Shepherd & Consumer & 87 & 0.1660 & $\begin{array}{l}0.0705 * * \\
(3.15)\end{array}$ & .094 \\
\hline$(1-c)$ & Census & Consumer & 86 & 0.7134 & $\begin{array}{l}0.0672 * * \\
(4.16)\end{array}$ & .161 \\
\hline$(2-a)$ & Census & $\begin{array}{l}\text { Consumer } \\
\text { Non-Dur. }\end{array}$ & 54 & 1.4696 & $\begin{array}{l}0.0644 * \\
(2.07)\end{array}$ & .058 \\
\hline$(2-b)$ & Shepherd & $\begin{array}{l}\text { Consumer } \\
\text { Non-Dur. }\end{array}$ & 54 & 0.8491 & $\begin{array}{l}0.0621 * \\
(1.98)\end{array}$ & .052 \\
\hline$(2-c)$ & Census & $\begin{array}{l}\text { Consumer } \\
\text { Non-Dur. }\end{array}$ & 53 & 0.8832 & $\begin{array}{l}0.0673 * * \\
(3.11)\end{array}$ & .143 \\
\hline$(3-a)$ & Census & $\begin{array}{l}\text { Consumer } \\
\text { Durables }\end{array}$ & 33 & 0.3745 & $\begin{array}{l}0.0686 * * \\
(2.81)\end{array}$ & .177 \\
\hline$(3-b)$ & Shepherd & $\begin{array}{l}\text { Consumer } \\
\text { Durables }\end{array}$ & 33 & -1.0879 & $\begin{array}{l}0.0874 * * \\
(3.22)\end{array}$ & .226 \\
\hline$(4-a)$ & Census & Producer & 237 & 0.5790 & $\begin{array}{l}0.0089 * * \\
(2.44)\end{array}$ & .021 \\
\hline$(4-b)$ & Shepherd & Producer & 237 & 0.7520 & $\begin{array}{l}0.0032 \\
(0.83)\end{array}$ & -.001 \\
\hline$(5-a)$ & Census & $\begin{array}{l}\text { Producer } \\
\text { Non-Dur. }\end{array}$ & 184 & 0.6340 & $\begin{array}{l}0.0077 * \\
(1.95)\end{array}$ & .015 \\
\hline$(5-b)$ & Shepherd & $\begin{array}{l}\text { Producer } \\
\text { Non-Dur. }\end{array}$ & 184 & 0.8950 & $\begin{array}{l}0.0005 \\
(0.12)\end{array}$ & -.005 \\
\hline$(6-a)$ & Census & $\begin{array}{l}\text { Producer } \\
\text { Durables }\end{array}$ & 53 & 0.3772 & $\begin{array}{l}0.0128 \\
(1.45)\end{array}$ & .021 \\
\hline$(6-b)$ & Shepherd & $\begin{array}{l}\text { Producer } \\
\text { Durables }\end{array}$ & 53 & 0.3551 & $\begin{array}{l}0.0108 \\
(1.20)\end{array}$ & .008 \\
\hline
\end{tabular}

$R^{2}$ is adjusted for degrees of freedom.

The $t$-values are in parentheses.

* Significant at .05 level.

** Significant at .01 level.

durable consumer goods industries, for which the advertising-concentration relationship is generally expected to be the closest, a comparison of equations (2-a) and (2-b) in Table I reveals that the use of the Shepherd concentration data actually causes a slight decrease in the $R^{2}$ (from .058 to .052) as well as in the size of the regression coefficient. For the durable consumer goods industries, where, contrary to expectations, the results with the official concentra- 
Table II. Regressions of $A S R$ on $C R$ and $C R^{2}, 1967$

\begin{tabular}{|c|c|c|c|c|c|c|c|}
\hline Equation & Data & Sample & $\mathrm{N}$ & Int ercept & CR & $\mathrm{CR}^{2}$ & $\mathrm{R}^{2}$ \\
\hline$(1-a)$ & Census & Consumer & 87 & -0.1938 & $\begin{array}{l}0.1345 \\
(1.36)\end{array}$ & $\begin{array}{l}-0.0007 \\
(-0.72)\end{array}$ & .081 \\
\hline$(1-b)$ & Shepherd & Consumer & 87 & 0.2784 & $\begin{array}{l}0.0657 \\
(0.57)\end{array}$ & $\begin{array}{l}0.0000 \\
(0.04)\end{array}$ & .083 \\
\hline$(1-c)$ & Census & Consumer & 86 & 0.4308 & $\begin{array}{l}0.0824 \\
(1.10)\end{array}$ & $\begin{array}{l}-0.0002 \\
(-0.21)\end{array}$ & .151 \\
\hline$(2-a)$ & Census & $\begin{array}{l}\text { Consumer } \\
\text { Non-Dur. }\end{array}$ & 54 & 0.3939 & $\begin{array}{l}0.1218 \\
(0.83)\end{array}$ & $\begin{array}{l}-0.0006 \\
(-0.40)\end{array}$ & .043 \\
\hline$(2-b)$ & Shepherd & $\begin{array}{l}\text { Consumer } \\
\text { Non-Dur. }\end{array}$ & 54 & -0.7023 & $\begin{array}{l}0.1293 \\
(0.81)\end{array}$ & $\begin{array}{l}-0.0006 \\
(-0.41)\end{array}$ & .037 \\
\hline$(2-c)$ & Census & $\begin{array}{l}\text { Consumer } \\
\text { Non-Dur. }\end{array}$ & 53 & 1.5370 & $\begin{array}{l}0.0322 \\
(0.31)\end{array}$ & $\begin{array}{l}0.0004 \\
(0.35)\end{array}$ & .128 \\
\hline$(3-a)$ & Census & $\begin{array}{l}\text { Consumer } \\
\text { Durables }\end{array}$ & 33 & -1.5260 & $\begin{array}{l}0.1709 \\
(1.56)\end{array}$ & $\begin{array}{l}-0.0011 \\
(-0.96)\end{array}$ & .175 \\
\hline$(3-b)$ & Shepherd & $\begin{array}{l}\text { Consumer } \\
\text { Durables }\end{array}$ & 33 & 2.8771 & $\begin{array}{l}-0.0824 \\
(-0.57)\end{array}$ & $\begin{array}{l}0.0016 \\
(1.19)\end{array}$ & .236 \\
\hline$(4-a)$ & Census & Producer & 237 & 0.4802 & $\begin{array}{l}0.0147 \\
(1.04)\end{array}$ & $\begin{array}{l}-0.0001 \\
(-0.42)\end{array}$ & .017 \\
\hline$(4-b)$ & Shepherd & Producer & 237 & 0.3297 & $\begin{array}{l}0.0223 \\
(1.25)\end{array}$ & $\begin{array}{l}-0.0002 \\
(-1.09)\end{array}$ & -.001 \\
\hline$(5-a)$ & Census & $\begin{array}{l}\text { Producer } \\
\text { Non-Dur. }\end{array}$ & 184 & 0.4487 & $\begin{array}{l}0.0191 \\
(1.21)\end{array}$ & $\begin{array}{l}-0.0001 \\
(-0.75)\end{array}$ & .013 \\
\hline$(5-b)$ & Shepherd & $\begin{array}{l}\text { Producer } \\
\text { Non-Dur. }\end{array}$ & 184 & 0.4780 & $\begin{array}{l}0.0193 \\
(0.93)\end{array}$ & $\begin{array}{l}-0.0002 \\
(-0.92)\end{array}$ & -.006 \\
\hline$(6-a)$ & Census & $\begin{array}{l}\text { Producer } \\
\text { Durables }\end{array}$ & 53 & 0.4062 & $\begin{array}{l}0.0113 \\
(0.32)\end{array}$ & $\begin{array}{l}0.0000 \\
(0.04)\end{array}$ & .001 \\
\hline$(6-b)$ & Shepherd & $\begin{array}{l}\text { Producer } \\
\text { Durables }\end{array}$ & 53 & -0.1708 & $\begin{array}{l}0.0345 \\
(0.93)\end{array}$ & $\begin{array}{l}-0.0002 \\
(-0.66)\end{array}$ & -.003 \\
\hline
\end{tabular}

$R^{2}$ is adjusted for degrees of freedom.

The $t$-values are in parentheses.

* Significant at .05 level.

** Significant at .01 level.

tion ratios are much the strongest, a comparison of equations (3-a) and (3-b) in Table I reveals that the use of the Shepherd concentration data provides a moderate boost to both the $R^{2}$ (raising it from .177 to .226) and the size of the regression coefficient. Overall, for consumer goods industries generally, the use of the adjusted concentration data has had what many will surely regard as a surprisingly small effect on the regression results. 
In contrast to the foregoing results, the dropping of a single industry from the sample brings about a substantial increase in the $R^{2}$. The toiletries industry (SIC 2844) has an advertising-sales ratio of 28.77 percent for 1967, nearly six standard deviations above the mean ( 4.34 percent) for all consumer goods industries in the sample. Using the official concentration ratios but dropping this industry from the sample of all consumer goods industries, we get equation (1-c), which can be compared to equation (1-a). The $R^{2}$ nearly doubles (from .086 to .161), although the regression coefficient rises only slightly. Equation (2-c) shows the effect of dropping this industry from the consumer non-durables sample. A comparison of (2-c) with (2-a) reveals that the $R^{2}$ more than doubles (from .058 to .143), although again the regression coefficient rises only slightly. Apparently, the presence in the sample of a single industry with an extreme advertising-sales ratio plays a much larger role in reducing the correlation between advertising and concentration than does the existence of errors in the measurement of concentration generally. This high degree of sensitivity of results to the exact composition of the sample thus continues to confound efforts to reach settled conclusions on the issues raised in the advertising-concentration controversy.

The results for consumer goods industries clearly are affected little by the use of the adjusted concentration data. We next present results for producer goods industries. Ornstein argued, with little supporting evidence, that large firms in an industry typically advertise more intensively than small firms, and that this results in spurious correlation between advertising intensity and concentration, since the higher the concentration, the greater the weight that large firms' advertising intensity would have in the measurement of average industry advertising intensity. He claimed support for this hypothesis from the fact that, although the advertising-concentration relationship appears considerably weaker in producer goods industries, it is nonetheless statistically significant for both producer and consumer goods industries.

The use of the adjusted concentration data can be seen to destroy the statistical support for the foregoing argument. Equations (4-a) and (4-b) in Table I show results for all producer goods industries using the official and adjusted concentration ratios, respectively, while equations (5-a) and (5-b) show results for producer non-durables. In each case the $t$-values for the regression coefficients plummet with the use of the Shepherd data, and statistical significance disappears. Equations (6-a) and (6-b) show comparative results for producer durables. The relationship is not statistically significant with either set of concentration data, but use of the Shepherd data again worsens the "statistical fit." If there is spurious correlation between advertising and concentration, it fails to show up in producer goods industries.

For the sake of completeness, we present in Table II the results using the quadratic estimating equation for each subsample. Each quadratic equation in Table II corresponds to the identically numbered linear equation in Table I. 
The quadratic results require little commentary. The regression coefficients sometimes have the wrong signs, and in no case are they statistically significant. Furthermore, a comparison of Tables I and II shows that, regardless of which set of concentration data is used, the addition of $C R^{2}$ to the estimating equation almost invariably causes the adjusted $R^{2}$ to decline. If Ornstein found no support for the quadratic functional form, it is fair to state that we have found even less.

\section{Summary and Conclusions}

Our overall results with adjusted concentration data generally support Ornstein's prior conclusions arrived at using the official concentration data. Using the adjusted concentration data, a statistically significant but not particularly strong linear relationship between advertising intensity and concentration shows up in consumer goods industries. However, such a relationship does not show up at all in producer goods industries, and the statistical relationship in consumer goods industries may well reflect some average net tendency for advertising competition to intensify as the degree of oligopoly increases, rather than being merely the result of large-firm effects. If so, there is no evidence that this net tendency is curbed by collusion at high levels of concentration, for results with the quadratic form continue to be very poor, whether concentration ratios are adjusted or not.

Although the correction of errors in the official Census concentration ratios has had little effect on the statistical estimation of the advertisingconcentration relationship, it would be inappropriate to assume that the same would hold true in the testing of other relationships, such as that between concentration and profitability. As noted earlier, Shepherd's adjustments were often substantial, but apparently many of the errors in the official concentration ratios were offsetting in terms of their effect on the advertisingconcentration relationship. Nonetheless, such errors remain a serious drawback in the use of the official Census concentration ratios for statistical analyses in industrial organization.

Brian C. Brush Marquette University

\section{References}

1. Bain, Joe S. Industrial Organization (2nd ed.). New York: John Wiley \& Sons, Inc., 1968.

2. Cable, John, "Market Structure, Advertising Policy and Intermarket Differences in Advertising Intensity," in Market Structure and Corporate Behavior, edited by K. Cowling. London: Gray Mills, 1972, pp. 107-24.

3. Greer, Douglas, "Advertising and Market Concentration." Southern Economic Journal, July 1971, 19-32. 
4. Ornstein, Stanley I., "The Advertising-Concentration Controversy," Southern Economic Journal, July 1976, 892-902.

5. Industrial Concentration and Advertising Intensity. Washington, D.C.: American Enterprise Institute for Public Policy Research, 1977.

6. Scherer, F. M. Industrial Market Structure and Economic Performance. Chicago: Rand McNally \& Co., 1970.

7. Shepherd, William G. Market Power and Economic Welfare. New York: Random House, 1970.

8. Strickland, Allyn D. and Leonard W. Weiss, "Advertising, Concentration, and Price-Cost Margins." Journal of Political Economy, October 1976, 1109-21.

9. Yule, G. U. and M. G. Kendall. An Introduction to the Theory of Statistics (14th ed.). London: Charles Griffen \& Co., Ltd., 1950. 